\title{
Zastosowanie stopy społecznego zwrotu z inwestycji (SROI) jako wskaźnika mierzenia efektywności projektów społecznych
}

\author{
DOI: $10.19195 / 1643-0328.21 .5$
}

Słowa kluczowe: stopa społecznego zwrotu z inwestycji, SROI, projekty społeczne, efektywność projektów społecznych, inwestycyjna polityka społeczna, inwestycje społeczne

\section{Wprowadzenie}

Główne wyzwania współczesnej polityki społecznej wiążą się z koniecznością pogodzenia odpowiedzi na rosnące potrzeby społeczne z ograniczeniami budżetowymi. Stąd wywodzi się postulat projektowania działań społecznych przy uwzględnieniu ich użyteczności, skuteczności i efektywności. W perspektywie proinwestycyjnej polityki społecznej to właśnie efektywność, przy uwzględnieniu skuteczności działań, staje się postawową wytyczną podejmowania interwencji. Najkrócej efektywność zdefiniować można jako rezultat podjętych działań, opisany relacją uzyskanych efektów do poniesionych nakładów. Istotą oceny efektywności działań z zakresu polityki społecznej jest to, jaki jest bilans kosztów i korzyści. Przy czym główny problem dotyczący analizy projektów społecznych polega na tym, że nie wszystkie koszty i korzyści mają charakter pieniężny. Stąd konieczność poszukiwania takich wskaźników efektywności, które w najbardziej adekwatny sposób ocenią realizowane projekty społeczne.

Artykuł prezentuje wyniki badań nad możliwością zastosowania stopy społecznego zwrotu z inwestycji (SROI, Social Return on Investment) do wyceny ekonomicznego rezultatu projektów społecznych realizowanych w ramach proinwestycyjnej polityki społecznej. Celem niniejszego artykułu jest przedstawienie możliwości zastosowania analizy SROI jako wskaźnika mierzenia efektywności projektów społecznych. W tym kontekście postawiono hipotezę, że stopa społecznego zwrotu z inwestycji (SROI) stanowi użyteczne narzędzie zarówno ewaluacji zrealizowanych projektów społecznych, jak i prognozowania efektywności planowanych przedsięwzięć. Dla realizacji celu badawczego postawiono następujące pytania badawcze: 
1. Jakie jest znaczenie pomiaru efektywności społecznej projektów społecznych we współczesnej polityce społecznej?

2. Czym różni się SROI od innych metod ewaluacji ekonomicznej projektów społecznych?

3. Jaka jest praktyczna implementacja SROI dla ewaluacji projektów społecznych?

4. Jaka jest możliwość zastosowania SROI do prognozowania efektywności projektów społecznych?

5. Jakie wady i zalety wiążą się z zastosowaniem analizy SROI?

Odpowiedzi na postawione pytania badawcze, zawarte w kolejnych częściach artykułu, pozwoliły na weryfikację postawionej hipotezy. W tekście omówiono znaczenie pomiaru efektywności projektów społecznych w kontekście paradygmatu proinwestycyjnej polityki społecznej, zaprezentowano założenia analizy SROI na tle innych metod ewaluacji ekonomicznej projektów społecznych, omówiono główne zasady i przebieg tej analizy oraz wskazano na wady i zalety jej stosowania.

W artykule wykorzystano metodę desk research, w ramach której analizie poddano dostępną literaturę przedmiotu z zakresu metodologii nauk społecznych i zarządzania publicznego dotyczącą SROI. Przedstawione wyniki badań uzyskane zostały w ramach realizacji naukowego projektu badawczego Innovative Social Investment Strengthening Communities in Europe (InnoSi), finansowanego przez Komisję Europejską z Programu Horyzont 2020.

\section{Znaczenie pomiaru efektywności projektów społecznych w kontekście paradygmatu proinwestycyjnej polityki społecznej}

Wyzwania wobec polityki społecznej w XXI wieku skupiają się wokół rosnących potrzeb społecznych i wymuszających ograniczanie działań redystrybucyjnych problemów budżetowych. Jednocześnie zmiany demograficzne, narastające problemy społeczne wywołane niestabilną sytuacją finansową i ekonomiczną oraz wzrastający poziom potrzeb społecznych sprawiają, że konieczne jest podejmowanie działań mających na celu nie tylko zaspokajanie bieżących potrzeb i rozwiązywanie aktualnych problemów społecznych, lecz także realizację zadań sprzyjających rozwojowi społeczeństw oraz przeciwdziałających pojawianiu się negatywnych zjawisk społecznych w przyszłości.

Wychodząc naprzeciw tym wyzwaniom, zmiany w prowadzeniu polityki społecznej w państwach europejskich opierają się w dużej mierze na wdrażaniu takich programów oraz projektów społecznych, które rozwiązując obecne problemy lub zaspokajając bieżące potrzeby, gwarantują występowanie korzyści społecznych również w przyszłości. Służyć ma temu promowanie nowego paradygmatu przygotowywania i wdrażania rozwiązań w dziedzinie polityki społecznej, opartego na inwestycjach społecznych ${ }^{1}$. Warto zwrócić uwagę, iż w Europie znaczenie inwestycji społecznych jako platformy zaangażo-

1 Zob. N. Morel, B. Palier, J. Palme, Polityka społeczna jako inwestycja, przeł. J. Karwacka Warszawa 2015. 
wania politycznego wzrosło wraz z postępami we wdrażaniu Pakietu Inwestycji Społecznych przyjętego w 2013 roku $^{2}$.

Podstawą paradygmatu inwestycji społecznych w Europie jest założenie, że wyzwania społeczeństw postindustrialnych, takie jak starzenie się społeczeństwa, zmiana struktury gospodarstw domowych oraz rozwój gospodarki opartej na wiedzy, sprawiają, że człowiek napotyka w trakcie swojego życia wiele problemów, z którymi wcześniej się nie spotykał i które wymagają od niego poszukiwania nowych sposobów ich rozwiązywania. To samo dotyczy polityki społecznej, która rozwiązując problemy współczesnego człowieka, musi uwzględniać możliwość wstępowania przyszłych potrzeb i problemów społecznych, które wymagać będą nowych sposobów realizacji zadań w ramach polityki publicznej ${ }^{3}$. Proinwestycyjna polityka społeczna dotyczy tych obszarów polityki społecznej, które inwestują w rozwój kapitału ludzkiego (m.in. opieka nad dzieckiem, oświata, edukacja wyższa, kształcenie ustawiczne), umożliwiają jego wykorzystanie (głównie polityka rynku pracy) oraz sprzyjają inkluzji społecznej (m.in. polityka rynku pracy, pomoc społeczna). Główną cechą tego podejścia jest postrzeganie działań z zakresu polityki społecznej jako produktywnych, niezbędnych do rozwoju gospodarczego i wzrostu zatrudnienia ${ }^{4}$.

Inwestycje społeczne mogą stanowić jedną z odpowiedzi na problemy związane z globalnym kryzysem gospodarczym oraz wyzwaniami demograficznymi ${ }^{5}$. Warto zwrócić uwagę, że zwiększenie roli inwestycji społecznych wynika z modyfikacji celów polityki Unii Europejskiej, która opiera się na skorelowaniu celów polityki spójności z celami polityki gospodarczej UE. Polityka spójności poprzez silne połączenie jej z polityką gospodarczą nabrała od 2014 roku charakteru ściśle proinwestycyjnego, w tym również w wymiarze spójności społecznej. Zmiana charakteru instrumentów polityki spójności z narzędzi rozwojowych w narzędzia proinwestycyjne sprawiła, że możliwe było przypisanie funduszom strukturalnym, w tym Europejskiemu Funduszowi Społecznemu (EFS), roli głównych narzędzi realizacji Strategii „Europa 2020”. Jednocześnie przeciwdziałanie negatywnym skutkom procesów demograficznych oraz konsekwencjom kryzysu finansów publicznych wywołanego sytuacją gospodarczą w Europie w drugiej

2 Social Investment Package, Evidence on Demographic and Social Trends Social Policies' Contribution to Inclusion, Employment and the Economy, Communication from the Commission to the European Parliament, the Council, the European Economic and Social Committee and the Committee of the Regions: Towards Social Investment for Growth and Cohesion - including implementing the European Social Fund 2014-2020, 20.2.2013, SWD 2013, 38 final I/I, Brussels.

3 Zob. P. Taylor-Gooby, New risks and social change, [w:] New risks, new welfare: The transformation of the European welfare state, red. P. Taylor-Gooby, London 2004, s. 191-205; F. Vandenbroucke, K. Vleminckx, Disappointing Poverty Trends: Is the Social Investment State to Blame?, „Journal of European Social Policy” 21, 2011, nr 5, s. 450-471; K. van Kersbergen, A. Hemerijck, Two decades of change in Europe: the emergence of the social investment state, „Journal of Social Policy” 41, 2012, nr 3, s. 475-492.

${ }^{4}$ N. Morel, B. Palier, J. Palme, Wykraczając poza dotychczasowe rozumienie państwa opiekuńczego?, [w:] N. Morel, B. Palier, J. Palme, op. cit., s. 1-3.

5 A. Wiktorska-Święcka, D. Moroń, M. Klimowicz, Zarządzanie innowacjami społecznymi. Trendy, perspektywy, wyzwania, Warszawa 2015, s. 74. 
dekadzie XXI wieku stało się wyzwaniem dla wszystkich państw członkowskich Unii Europejskiej.

Dlatego też Komisja Europejska wskazuje, iż dobrze zaprojektowane rozwiązania $\mathrm{w}$ ramach polityki społecznej, łączące znaczące inwestycje społeczne $\mathrm{z}$ dwiema pozostałymi funkcjami (ochroną i stabilizacją), zwiększać mogą jej skuteczność i efektywność́. W tym kontekście we wdrażaniu inwestycji społecznych znaczenia nabiera potrzeba mierzenia społecznej oraz ekonomicznej skuteczności i efektywności realizacji programów i projektów społecznych. Paradygmat inwestycji społecznych jest bowiem postrzegany jako czynnik wzmacniający efektywność polityki społecznej ${ }^{7}$.

Realizacja działań z zakresu polityki społecznej wiąże się często z osiąganiem celów o charakterze niemierzalnym. Rezultaty projektów społecznych są możliwe do opisania, trudniejsze zaś do zmierzenia, a jeszcze trudniejsze do oszacowania w wartościach ekonomicznych. Głównym kryterium ewaluacyjnym projektów społecznych jest ich skuteczność oznaczająca poziom osiągnięcia korzyści społecznych w trakcie i po ich realizacji. Ocena skuteczności zmierza do tego, aby stwierdzić, czy wybrane metody działania przyczyniły się do osiągnięcia założonych celów, rozwiązania problemów oraz czy zastosowane metody i środki są w zgodzie z potrzebami i wartościami beneficjentów danego projektu. Oszacowanie skuteczności projektu społecznego stanowi zatem ocenę społecznego wpływu (social impact), jaki dany projekt wywiera na jego odbiorców oraz ich otoczenie środowiskowe, społeczne i gospodarcze.

W kontekście wdrażania projektów społecznych w oparciu o paradygmat inwestycji społecznych coraz większe znaczenie przypisuje się ich efektywności. O efektywności projektu społecznego można mówić w sytuacji, kiedy uzyskane efekty danego projektu przewyższają koszty poniesione na jego realizację. Można ją zmierzyć, porównując nakłady finansowe lub zmonetaryzowane (inputs) z osiągniętymi efektami - produktami lub rezultatami (outputs, outcomes). Jednocześnie uzyskane efekty muszą odnosić się do założonych celów.

Oilejednakłatwo zmierzyć efekty policzalne(tj. mierzalnewjednostkach monetarnych), o tyle (dużo) trudniej oszacować korzyści niematerialne, takie jak np. korzyść czy zmiana społeczna. Trudnościom tym wychodzą naprzeciw proponowane przez różne ośrodki badawcze metody ewaluacji ekonomicznej społecznych korzyści z realizacji polityk publicznych oraz wdrażania programów i projektów społecznych. Ewaluacja ekonomiczna polityk publicznych, programów oraz projektów koncentruje się na planowaniu działań publicznych i zapewnieniu efektywności wykorzystania zasobów, przy wykorzystaniu określonych metod oszacowania niefinansowych kosztów i korzyści w jednostkach pieniężnych.

Poniżej zaprezentowane zostaną najważniejsze metody analizy ekonomicznej stosowane obecnie przy ewaluacji efektywności wdrażania projektów społecznych.

${ }^{6}$ Zob. European Commission, Towards Social Investment..., s. 3.

7 A. Wiktorska-Święcka et al., Report on scientific literature review on the concept "Social Investment”. A deliverable of the project: „Innovative Social Investment: Strengthening communities in Europe” (InnoSI), European Commission - Horizon 2020, European Commission, Research Executive Agency, Brussels 2016, s. 7. 


\section{Analiza SROI na tle innych metod ewaluacji ekonomicznej projektów społecznych}

Głównym celem projektów społecznych jest osiąganie korzyści społecznych. Samo jednak pojęcie korzyści społecznych funkcjonuje w wielu kontekstach i ujęciach, co sprawia dużą trudność w jednoznacznym jego zdefiniowaniu. Niemniej jednak w funkcjonujących modelach opisywania społecznego oddziaływania projektów społecznych główne miejsce zajmują społeczna wartość dodana oraz zysk społeczny. W największym uproszczeniu można przyjąć, że oba te pojęcia odnoszą się do mierzalnego aspektu oddziaływania społecznego, przy czym pojęcie zysku społecznego kładzie nacisk na miary poddające się przeliczeniu finansowemu. Społeczna wartość dodana ma zaś charakter o wiele szerszy, gdyż poza tym, co można zmierzyć w jednostkach pieniężnych, odnosi się także do tych efektów projektów społecznych, którym trudniej jest przypisać wartość finansową.

Ewaluacja ekonomiczna zapewnia zatem punkt odniesienia dla zysku społecznego oraz społecznej wartości dodanej poprzez uwzględnienie relacji wielkości poniesionych kosztów do osiągniętych wyników realizacji programów i projektów. W ramach analizy ekonomicznej projektów społecznych poszukuje się zatem odpowiedzi na następujące pytania:

1. Jaki był rzeczywisty koszt projektu społecznego?

2. Czy osiągnięte rezultaty uzasadniają inwestycję zasobów w projekt?

3. Jakie były korzyści społeczne związane z projektem dla różnych podmiotów w niego zaangażowanych?

4. Czy osiągnięty rezultat byłby możliwy przy niższych kosztach dzięki zastosowaniu alternatywnego sposobu działania?

Tradycyjnie w ewaluacji ekonomicznej polityk publicznych, programów i projektów społecznych wykorzystuje się najczęściej następujące typy analiz: analizę wydajności kosztów (CBA, Cost Benefit Analysis), analizę efektywności kosztów (CEA, Cost Effectiveness Analysis) oraz analizę użyteczności kosztów (CUA, Cost Utility Analysis) ${ }^{8}$. Rozwój badań nad ewaluacją ekonomiczną przedsięwzięć społecznych sprzyja rozwijaniu siatki metod, technik i narzędzi oceny efektywności projektów społecznych. W dużej mierze są one zaczerpnięte z rozwijającej się ewaluacji oddziaływania podmiotów ekonomii społecznej. W poszczególnych krajach, w których powstawały inicjatywy ekonomii społecznej, tworzono różne narzędzia do oceny efektów działania podmiotów trzeciego sektora. Do najbardziej rozpowszechnionych metod pomiaru efektywności podmiotów ekonomii społecznej i ich wpływu na otoczenie społeczne należą: stopa społecznego zwrotu z inwestycji (Social Return on Investment), audyt społeczny (Social Audit), zrównoważona karta wyników (Social Enterprise Balanced Scorecard), narzędzie Prove It! (Udowodnij to!), metoda potrójnego wyniku finansowego (Triple Bottom

8 O. Banke-Thomas et al., Social Return on Investment (SROI) methodology to account for value for money of public health interventions: A systematic review, „BMC Public Health” 2015, nr 12 (582), s. 3. 
Line) oraz metoda Proces U2, czyli Proces Udowodnij i Udoskonal (Process Prove and Improve $)^{9}$.

Na tle wymienionych metod ewaluacji ekonomicznej na uwagę zasługuje stopa społecznego zwrotu z inwestycji. Jako jedna z nielicznych metod pozwala ona zarówno na oszacowanie wartości zrealizowanych projektów społecznych, jak i na prognozowanie zwrotu z zainwestowanych środków finansowych w przyszłe projekty.

Social Return on Investment (SROI), czyli stopa społecznego zwrotu z inwestycji, to narzędzie służące do analizy mechanizmów powstawania i trwania wpływu organizacji na społeczeństwo, środowisko i gospodarkę, mierzenia wartości tego wpływu i raportowania go ${ }^{10}$. Łączy ona w sobie zalety analizy kosztów oraz korzyści audytu społecznego. Oryginalność metody polega na możliwości monetarnego przedstawienia wszystkich (lub przynajmniej większości) istotnych nakładów i skutków danego projektu społecznego. Przeliczenie wpływu społecznego na pieniądze jest możliwe poprzez określenie relacji łącznego finansowego wkładu do projektu społecznego oraz zmonetaryzowanych inwestycji niefinansowych do zsumowanych korzyści finansowych oraz zmonetaryzowanych skutków z realizacji projektu (ryc. 1).

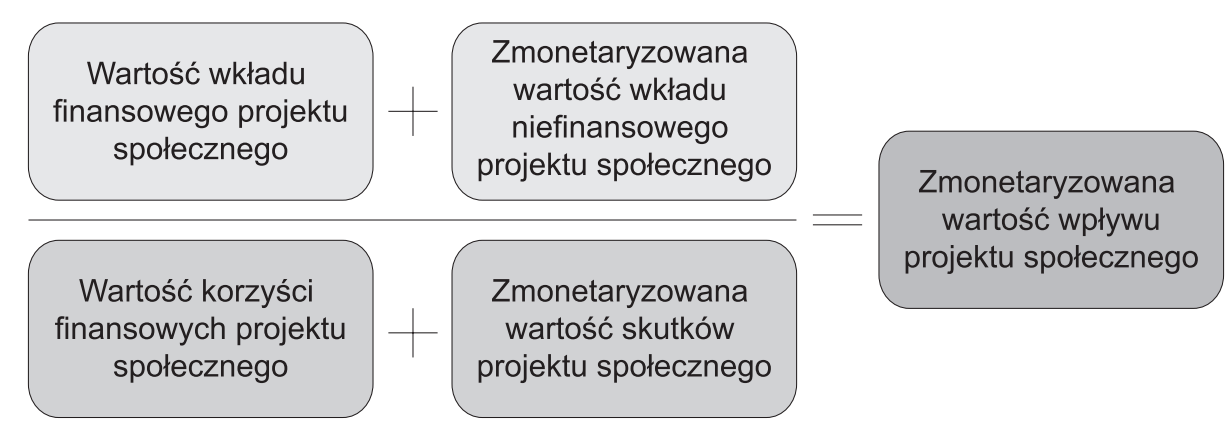

Rycina 1. Sposób określania wartości/efektywności wpływu projektu społecznego w ramach SROI Źródło: Opracowanie własne.

Wskaźnik SROI przedstawia stosunek inwestycji w przedsięwzięcie (projekt) do korzyści, jakie uzyskało lub uzyskałoby z niego społeczeństwo ${ }^{11}$. Można go zatem wykorzystywać dwojako - zarówno jako metodę ewaluacji społecznej stopy zwrotu ze zrealizowanej inwestycji, jak i prognozę społecznej stopy zwrotu z przygotowywanego projektu społecznego. Ewaluacja jest przeprowadzana po zakończeniu danego projektu, a jej podstawą są osiągnięte dotychczas wyniki. Prognozę natomiast wykorzystuje się na etapie przygotowywania projektu, planowania jego kosztów i korzyści. Ewaluacyjny

${ }^{9}$ Zob. I. Łącka, Problemy oceny efektywności podmiotów ekonomii społecznej, [w:] Finanse i rachunkowość na rzecz zrównoważonego rozwoju - odpowiedzialność, etyka, stabilność finansowa, t. 1. Finanse, red. G. Borys, R. Kurek, Wrocław 2015, s. 245.

${ }^{10}$ N. Matuszak, Analiza SROI. Ile warta jest społeczna odpowiedzialność? Waloryzacja w raportowaniu społecznym, [w:] Mierzenie efektywności i wplywu społecznego działań CSR, red. N. Ćwik, Warszawa 2012, s. 39.

11 J. Nicholls et al., A Guide to Social Return on Investment, Cabinet Office 2009, s. 9. 
charakter SROI opiera się na analizie obserwowanych efektów zrealizowanego już projektu społecznego, prognostyczny umożliwia zaś oszacowanie kosztów i korzyści przy założeniu, że projekt zostanie zrealizowany.

\section{Główne zasady i etapy analizy SROI}

Analiza SROI opiera się na siedmiu głównych zasadach, które stanowią jej postawę i muszą być uwzględnione dla poprawnego przeprowadzenia analizy:

1. Zaangażowanie interesariuszy - interesariusze (stakeholders) to podmioty (osoby, organizacje, instytucje), które doświadczyły zmian w wyniku realizacji projektu społecznego. Analiza SROI zakłada ich zidentyfikowanie oraz uwzględnienie ich punktu widzenia w prowadzeniu analizy dotyczącej nakładów, produktów i rezultatów działań.

2. Zidentyfikowanie zmiany społecznej — analiza SROI zakłada, że realizacja projektu prowadzi do wystąpienia zmiany (zmian), która powinna być zidentyfikowana i opisana. Należy uwzględnić nie tylko zamierzone i pozytywne zmiany, lecz także dokonać analizy pod kątem zmian niezamierzonych i negatywnych. Wymaga to stworzenia lub wykorzystania teorii zmiany społecznej.

3. Zmonetaryzowanie wartości produktów i rezultatów - kluczowe w analizie SROI jest nie tylko określenie produktów i rezultatów, lecz także zmonetaryzowanie niefinansowych rezultatów działań.

4. Włączanie tylko istotnych elementów do analizy - na każdym etapie analizy konieczne jest podejmowanie decyzji dotyczących uwzględniania elementów istotnych i odrzucania tych, które nie są ważne z perspektywy oceny projektu.

5. Ograniczenie roszczeń dotyczących wpływu - ocenianie tylko tych rezultatów, za których wywołanie odpowiedzialny jest analizowany projekt, przy uwzględnieniu wkładu innych podmiotów w wywołanie analizowanych rezultatów.

6. Transparentność - konieczne jest wykazanie rzetelności przeprowadzonych analiz, wskazanie źródełi metod zbierania informacji, udokumentowaniei wyjaśnienie wyników.

7. Sprawdzenie wyników - wprawdzie analiza SROI daje możliwość pełnego spojrzenia na projekt, jednakże nieuchronnie towarzyszy jej subiektywność oceny, np. w odniesieniu do interesariuszy czy rezultatów. Wyniki powinny być przedstawione w taki sposób, aby możliwe było ich sprawdzenie i ocena, czy podjęte przez ekspertów prowadzących analizę decyzje były uzasadnione ${ }^{12}$.

Metodologia analizy SROI zakłada przeprowadzenie postępowania badawczego w sześciu etapach, z których każdy wymaga wykonania szczegółowo określonych analiz (ryc. 2).

12 Ibidem, s. 96-98. 


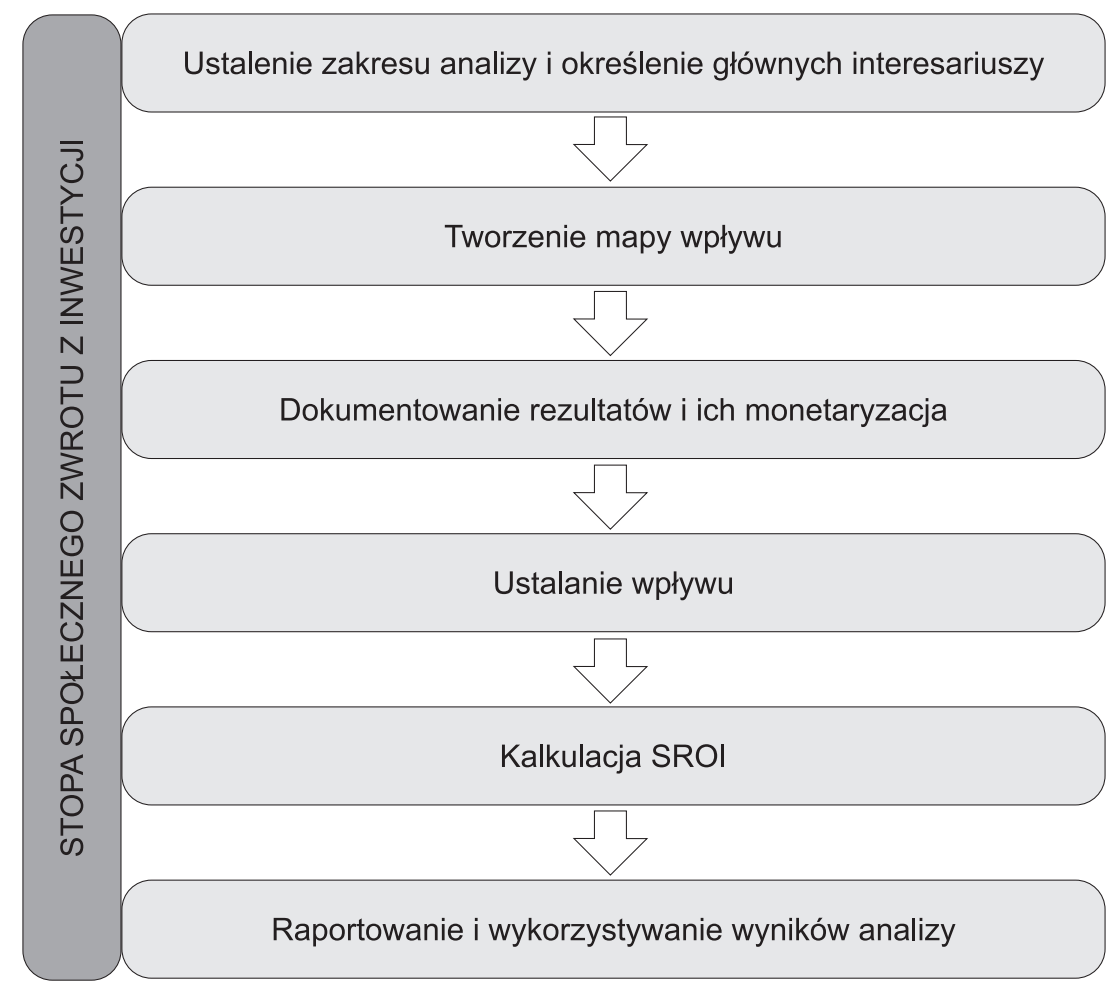

Rycina 2. Etapy analizy SROI

Źródło: Opracowanie własne na podstawie J. Nicholls et al., op. cit.

Etap pierwszy obejmuje ustalenie zakresu analizy i określenie głównych interesariuszy. Konieczne jest tutaj dokładne wyznaczenie zakresu ewaluacji, a więc wskazanie rodzaju działań podlegających ocenie (program, projekt, działalność organizacji - całość lub określona część działań), zakresu czasowego analizy, możliwych do wykorzystania źródeł informacji, w tym zaplanowanie badań empirycznych interesariuszy, którzy w analizie SROI stanowią istotne źródło informacji. Kolejnym elementem tego etapu jest wskazanie na interesariuszy ewaluowanych działań. Interesariusze (stakeholders) to wszyscy ci, na których oddziaływała analizowana działalność — zarówno w sposób pozytywny, jak i negatywny, zamierzony i niezamierzony. Szczegółowa analiza interesariuszy jest niezwykle ważną podstawą analizy SROI. Konieczne jest zwrócenie uwagi nie tylko na beneficjentów projektu (programu, działań), lecz także na innych interesariuszy - zarówno osoby fizyczne (rodziny i znajomych beneficjentów, pracowników, członków organizacji i wolontariuszy zaangażowanych w działania), jak i instytucje i organizacje (m.in. organizacje pozarządowe, instytucje publiczne, podmioty prywatne) oraz większe zbiorowości społeczne (lokalną społeczność, podatników, społeczeństwo), a także państwo. Następnie konieczne jest wyłonienie głównych interesariuszy, którzy odgrywają istotną rolę z perspektywy ewaluowanych działań, a więc w największym stopniu doty- 
czyły ich rezultaty. Taki wybór powinien zostać uzasadniony przez wskazanie przyczyn włączenia lub wyłączenia danych interesariuszy $\mathrm{z}$ analizy. W przypadku włączonych do analizy głównych interesariuszy należy określić sposób ich włączenia w prowadzenie analizy SROI i uzyskania informacji o odniesionych przez nich korzyściach (lub stratach). Informacje te mogą być pozyskane w sposób bezpośredni, dzięki przeprowadzeniu badań empirycznych (najczęściej wywiadów), lub pośrednio - przez wykorzystanie dostępnych materiałów i danych.

Kolejny, drugi etap to tworzenie mapy wpływu ewaluowanych działań, a więc określenie dla każdego z głównych interesariuszy poniesionych nakładów i ich pieniężnej wartości, uzyskanych produktów oraz rezultatów działań.

Etap trzeci obejmuje dokumentowanie rezultatów i ich monetaryzację. Skupiamy się tutaj na rezultatach ewaluowanych działań (zarówno pozytywnych, jak i negatywnych) i dla każdego z nich określamy sposób pomiaru, a więc wskaźnik oraz źródło informacji o nim. Następnie konieczna jest analiza wskaźników i wyznaczenie tych, w których przypadku możliwa jest monetaryzacja, a więc pieniężne określenie ich wartości. W analizie SROI kluczowa jest monetaryzacja jak największej liczby rezultatów, gdyż pozwala to na najbardziej precyzyjne określenie stopy społecznego zwrotu z inwestycji. Część rezultatów jest jednak - ze względu na swoją specyfikę — trudna lub wręcz niemożliwa do zmonetaryzowania, szczególnie w określonych warunkach społecznych. Kolejne działanie to określenie pieniężnej wartości poszczególnych wskaźników przy uwzględnieniu ilości wygenerowanych rezultatów i czasu ich trwania. W tabeli 1 przedstawiono przykładowe rezultaty działań i ich monetaryzację.

Etap czwarty to ustalanie faktycznego wpływu. Konieczne jest tu skorygowanie przyjętych w poprzednim etapie pieniężnych wartości rezultatów przy uwzględnieniu możliwych do wystąpienia efektów, takich jak: bieg jałowy (deadweight), przeniesienie (displacement) i przypisanie (attribution), a także uwzględnienie zmniejszania się zakresu rezultatów wraz $\mathrm{z}$ upływem czasu (drop-off). Efekt jałowego biegu związany jest $\mathrm{z}$ tym, że część rezultatów mogła zostać uzyskana bez realizacji działań ewaluowanych (np. część osób biernych zawodowo biorących udział w ewaluowanym projekcie mogła znaleźć pracę samodzielnie, bez udziału w nim). Efekt przeniesienia wskazuje natomiast, że realizacja działań projektu może przynosić negatywne skutki osobom, które z nich nie korzystały (np. podjęcie działań skierowanych do biernych zawodowo pomogło im znaleźć pracę, ale utrudniło znalezienie pracy innym, np. bezrobotnym, którzy bez wsparcia byli na gorszej pozycji w rywalizacji o stanowisko pracy). Efekt przypisania uwzględnia fakt, że nie tylko ewaluowane działania przyczyniły się do pozytywnych rezultatów, gdyż ich pojawienie się mogło być wywołane przez inne zdarzenia lub działania (np. osoby bezrobotne biorące udział w projekcie znalazły pracę nie dzięki wsparciu projektu, lecz ze względu na swoje własne działania, które podjęły przed uczestnictwem w projekcie). Ustalenie wpływu projektu musi też uwzględniać, że zakładane pozytywne rezultaty mogą się zmniejszać wraz z upływem czasu. Warto zwrócić uwagę, że metodologia SROI zakłada, iż wartości wszystkich powyższych efektów są określane w procentach, a następnie wszystkie pieniężne wartości rezultatów są pomniejszane o wyliczone pieniężne wartości tych efektów. 


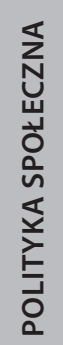

\begin{tabular}{|c|c|c|c|c|c|c|c|c|}
\hline 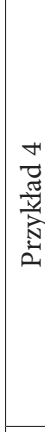 & 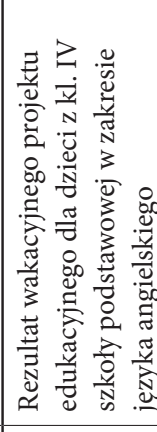 & 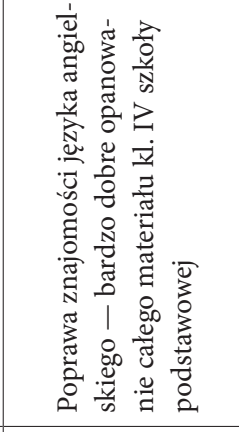 & 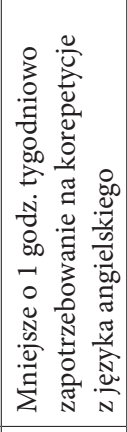 & 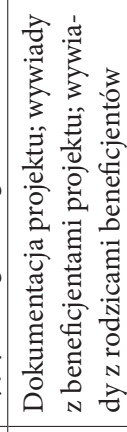 & in & 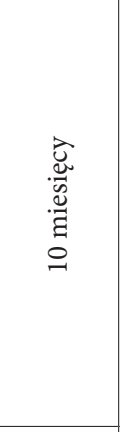 & 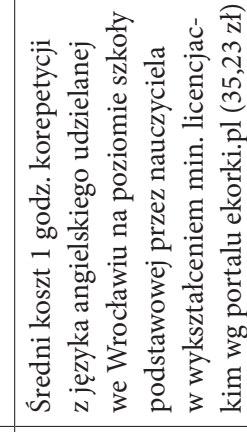 & 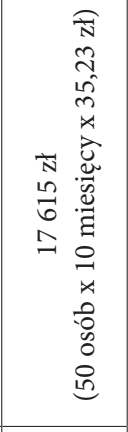 \\
\hline 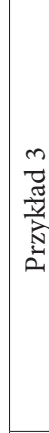 & 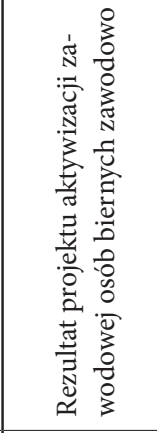 & 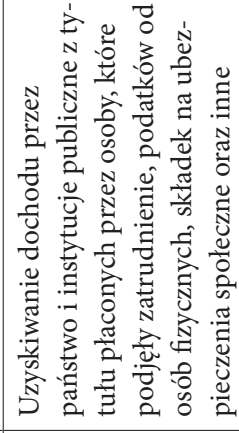 & 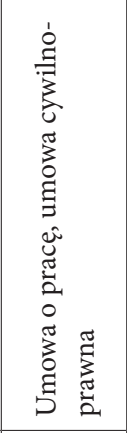 & 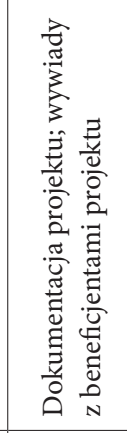 & নి & 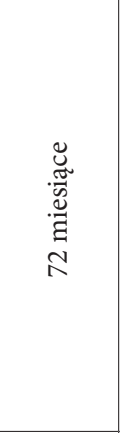 & 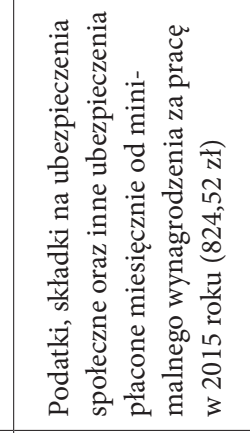 & 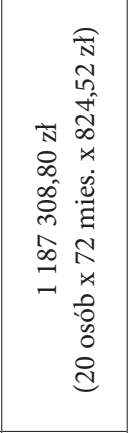 \\
\hline 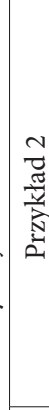 & 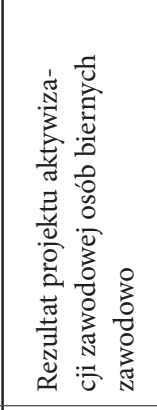 & 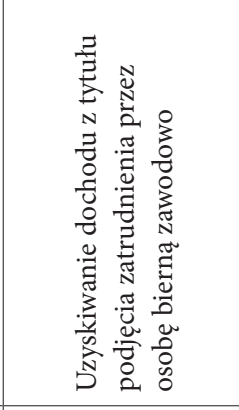 & 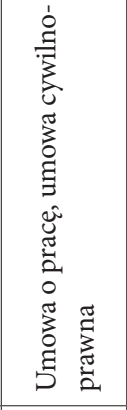 & 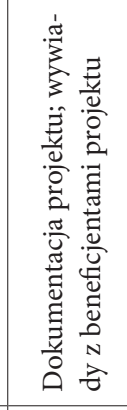 & i & 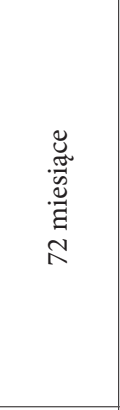 & 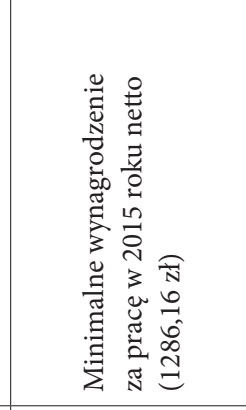 & 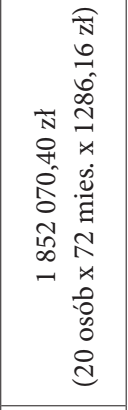 \\
\hline 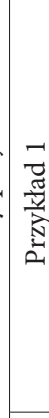 & 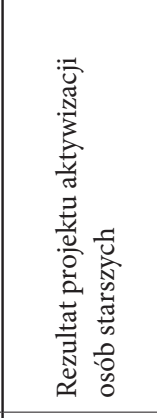 & 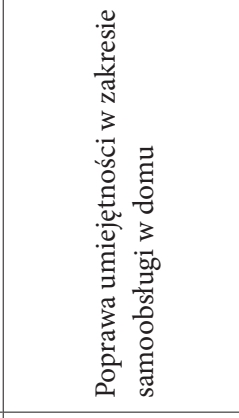 & 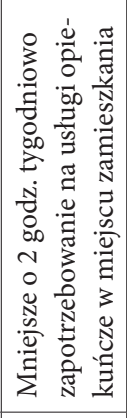 & 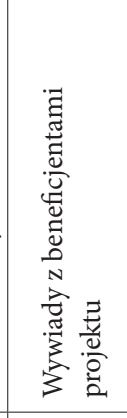 & F & 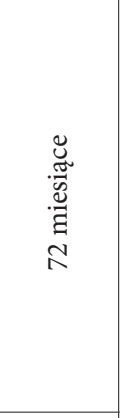 & 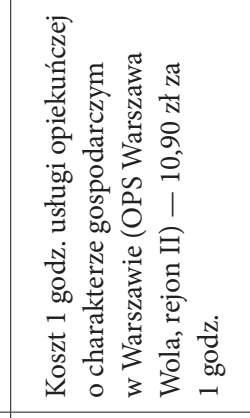 & 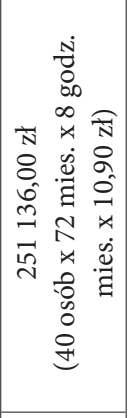 \\
\hline $\mathbb{N}$ & $\begin{array}{l}\frac{\mathrm{t}}{0} \\
\frac{0}{2}\end{array}$ & 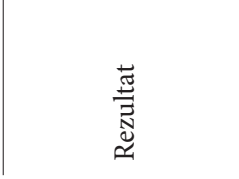 & 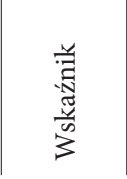 & 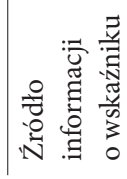 & & 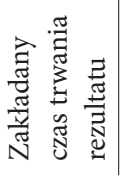 & 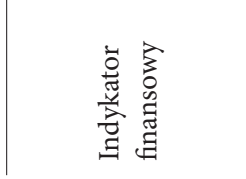 & $\begin{array}{l}\vec{N} \\
3 \\
3 \\
u \\
0 \\
0 \\
0 \\
3 \\
3\end{array}$ \\
\hline
\end{tabular}


Niekiedy bardzo trudno oszacować wartość poszczególnych efektów, czasami nie są one w ogóle znane. W takich wypadkach zalecane jest przeprowadzenie badań w grupie docelowej (lub uwzględnienie dostępnych badań).

Etap piąty polega na wyliczeniu wskaźnika SROI. Służy do tego wzór zaprezentowany poniżej:

$$
S R O I=\frac{P V}{T I},
$$

gdzie:

SROI - wskaźnik społecznego zwrotu z inwestycji (Social Return on Investment ratio)

$P V$ - łączna wartość rezultatów (Total Present Value)

TI - łączna wartość nakładów (Total Inputs).

Łączna wartość nakładów TI (Total Inputs) obliczana jest zgodnie z formułą:

$$
T I=\sum_{n=1}^{\infty} I_{n}
$$

gdzie:

TI - łączna wartość nakładów (Total Inputs)

I - nakład (Input).

Natomiast łączna wartość rezultatów PV (Total Present Value) uwzględniać powinna stopę dyskontową (dla sektora publicznego zakłada się jej wysokość na poziomie 3,5\%) i jest obliczana według wzoru:

gdzie:

$$
P V=\sum_{n=1}^{\infty} \frac{C F_{n}}{(1+r)^{n}}
$$

$P V$ - łączna wartość rezultatów (Total Present Value)

$C F$ - wartość rezultatów w roku $n$

$r$ - stopa dyskontowa.

Obliczony w ten sposób wskaźnik SROI wskazuje, jaki zwrot uzyskujemy z każdej zainwestowanej jednostki finansowej. Dla przykładu wskaźnik SROI na poziomie 2,5 oznacza, że z każdej zainwestowanej złotówki otrzymujemy zwrot w wysokości 2,5 zł, a więc 1,5 zł zysku. Po obliczeniu wskaźnika SROI można także dokonać analizy wrażliwości, w ramach której bada się zmienność wskaźnika przy zmianie różnych parametrów. Testujemy tutaj, które z elementów mają największy wpływ na wskaźnik SROI.

Ostatni etap to raportowanie i wykorzystywanie wyników analizy. Ważne jest upowszechnienie informacji zawartych $\mathrm{w}$ analizie wśród interesariuszy, a także innych podmiotów zainteresowanych projektem oraz wykorzystanie wyników analizy w projektowaniu przyszłych działan ${ }^{13}$.

13 Zob. ibidem; O. Banke-Thomas et al., op. cit.; E. Lawlor, H. Kersley, S. Steed, A Bit Rich: Calculating the Real Value to Society of Different Professions, London 2009; M. Oramus, Przydatność metody Social Return on Investment dla małych podmiotów ekonomii społecznej. Studium przypadku fundacji Ale heca!, „Ekonomia Społeczna” 2011, nr 2. 


\section{Użyteczność analizy SROI i wyzwania związane z jej prowadzeniem}

Analiza SROI należy do coraz częściej wykorzystywanych narzędzi ewaluowania projektów społecznych. Wynika to $\mathrm{z}$ jej niewątpliwych zalet wiążących się z tym, iż jest ona bardziej niż inne metody ekonomiczne (jak CBA czy CEA) adekwatna do oceny tych projektów, których rezultaty (a często częściowo i nakłady) nie mają charakteru stricte finansowego. Należy wskazać na następujące korzyści wynikające ze stosowania metody SROI:

1. Metodologia analizy SROI skupia się na długotrwałym wpływie projektu społecznego, pozwala przeanalizować jego oddziaływanie w przyjętej perspektywie czasowej (bądź w kilku perspektywach) przy uwzględnieniu zmniejszania się (lub zwiększania) rezultatów wraz z upływem czasu.

2. Analiza SROI wraz z czysto finansowymi kosztami i zyskami projektu społecznego uwzględnia konieczność zmonetaryzowania skutków społecznych projektu, co pozwala na pełniejsze przeanalizowanie zarówno nakładów (poza pieniędzmi może to być np. czas poświęcony przez wolontariuszy, członków organizacji, dobra o charakterze rzeczowym), jak i rezultatów.

3. Skutki są przedstawione z perspektywy beneficjentów ostatecznych, jak i głównych interesariuszy projektów społecznych. Szczególnie istotny jest w tym zakresie nacisk na uwzględnianie rezultatów z perspektywy różnych interesariuszy, a nie tylko beneficjentów projektu (np. podjęcie zatrudnienia przez beneficjenta projektu przynosi korzyść zarówno samemu beneficjentowi, jak i państwu, które notuje wpływy z podatków i składek na ubezpieczenia).

4. Analiza SROI uwzględnia możliwość zmonetaryzowania niezamierzonych oraz negatywnych skutków realizacji projektów społecznych, w tym uwzględnia negatywne oddziaływanie na osoby, które nie brały udziału w projekcie.

5. Stanowi dobre narzędzie planowania i ewaluacji partnerstw publiczno-prywatnych i innych form kooperacji międzysektorowych, ponieważ bada $\mathrm{z}$ równą dbałością opinie wszystkich interesariuszy.

Analiza SROI jest użyteczną metodą określania efektywności projektów społecznych, nie oznacza to jednak braku mankamentów związanych z jej stosowaniem. Kluczowa wydaje się w tym kontekście subiektywność prowadzonych analiz, która występuje pomimo dołożenia wszelkich starań w zakresie transparentności oraz dokładności prac. Problem może występować już na etapie identyfikowania interesariuszy i włączania ich w proces analizy, w dużym stopniu dotyczy jednak określania rezultatów i ich monetaryzacji. Analiza SROI zakłada możliwość monetaryzacji niefinansowych rezultatów działań, jednakże często jest to wyjątkowo trudne, a nawet niemożliwe, w odniesieniu do wszystkich rezultatów. Pojawia się bowiem problem monetaryzacji np. zadowolenia z życia, satysfakcji, poprawy nastroju, poprawy funkcjonowania społecznego. W przypadku wielu rezultatów dobór wskaźników ma charakter arbitralny i nie uwzględnia wszystkich możliwych opcji. Podobny problem dotyczy możliwości ustalenia faktycznego wpływu przez skorygowanie rezultatów o wartość efektów jałowego biegu, prze- 
niesienia i przypisania oraz uwzględnienia zmniejszania się rezultatów w czasie. Bardzo często obliczenia te mają charakter szacunkowy, co nie zapewnia pewności i powtarzalności wyników badań. W stosowaniu analizy SROI konieczne jest również uwzględnienie specyfiki krajowej i lokalnej, co często uniemożliwia stosowanie porównań. Niektóre wskaźniki możliwe do monetaryzacji w jednym kraju nie mogą być zastosowane w innym. Ze względu na różnice cen efekty finansowe mogą mieć też zupełnie odmienną wartość. Nie oznacza to jednak braku użyteczności analizy SROI, a jedynie konieczność uwzględnienia tych ograniczeń podczas prowadzenia i interpretacji analiz.

\section{Podsumowanie}

Przedstawione $\mathrm{w}$ artykule rozważania dotyczące stopy społecznego zwrotu $\mathrm{z}$ inwestycji oraz możliwości jej zastosowania do wyceny ekonomicznego rezultatu projektów społecznych pozwalają pozytywnie zweryfikować hipotezę wskazującą, iż analiza SROI jest użytecznym wskaźnikiem do mierzenia efektywności zrealizowanych i planowanych projektów społecznych. Wynika to z założeń analizy SROI uwzględniających wszystkich interesariuszy projektu oraz dążących do rozpoznania i włączenia produktów i rezultatów projektu oraz ich monetaryzacji w celu pełnej ekonomicznej wyceny projektu.

Przeprowadzone $\mathrm{w}$ artykule rozważania pozwalają na wyciągnięcie następujących wniosków:

1. Proinwestycyjna polityka społeczna, określając kierunki oddziaływań, opiera się nie tylko na skuteczności, lecz także - a często przede wszystkim - na efektywności działań. W związku z ograniczonymi środkami finansowymi kluczowa jest realizacja takich projektów społecznych, które doprowadzą do osiągnięcia założonych celów, i jednocześnie będą efektywne ekonomicznie. Analiza SROI jest w tym kontekście użyteczną metodą określania efektywności projektów.

2. Analiza SROI może być stosowana zarówno jako metoda ewaluacji już zrealizowanych działań, jak i jako metoda prognozowania efektywności inwestycji. Jest to wykonalne dzięki możliwości wykorzystania monetaryzacji do wyceny efektów zrealizowanych działań oraz planowanych rezultatów przyszłych działań. We współczesnej polityce społecznej istotne jest jej wykorzystanie w obu aspektach, a szczególnie korzystna wydaje się możliwość połączenia tych ujęć - tj. projektowania przyszłych działań w oparciu o prognozowaną ich efektywność przy uwzględnieniu wyników ekonomicznych już przeprowadzonych działań.

3. Analiza SROI jest szczególnie użyteczna w przypadku projektów społecznych mających charakter niefinansowy, a także takich, w których przypadku część nakładów jest niepieniężna. Dotyczy to zwłaszcza podmiotów trzeciego sektora, które często wnoszą wkład w postaci zasobów ludzkich, urządzeń czy infrastruktury. Możliwość finansowej wyceny rezultatów projektu przesądza o użyteczności tej metody. Pozwala ona bowiem pokazać w często dziś preferowany, finansowy sposób te zyski z prowadzonych działań, które często nie są dostrzegane przez otoczenie, a nawet podmioty finansujące projekty. 


\section{Bibliografia}

Banke-Thomas O. et al., Social Return on Investment (SROI) methodology to account for value for money of public health interventions: A systematic review, „BMC Public Health” 2015, nr 12 (582).

European Commission, Towards Social Investment for Growth and Cohesion - including implementing the European Social Fund 2014-2020, COM 83, Brussels 2013.

Kersbergen K. van, Hemerijck A., Two decades of change in Europe: The emergence of the social investment state, „Journal of Social Policy” 41, 2012, nr 3.

Lawlor E., Kersley H., Steed S., A Bit Rich: Calculating the Real Value to Society of Different Professions, New Economics Foundation, London 2009.

Łącka I., Problemy oceny efektywności podmiotów ekonomii społecznej, [w:] Finanse i rachunkowość na rzecz zrównoważonego rozwoju - odpowiedzialność, etyka, stabilność finansowa, t. 1. Finanse, red. G. Borys, R. Kurek, Prace Naukowe Uniwersytetu Ekonomicznego we Wrocławiu, Wrocław 2015.

Matuszak N., Analiza SROI. Ile warta jest społeczna odpowiedzialność? Waloryzacja w raportowaniu społecznym, [w:] Mierzenie efektywności i wpływu społecznego działań CSR, red. N. Ćwik, Forum Odpowiedzialnego Biznesu, Warszawa 2012.

Morel N., Palier B., Palme J., Polityka społeczna jako inwestycja, przeł. J. Karwacka, Wyższa Szkoła Pedagogiczna im. Janusza Korczaka w Warszawie, Warszawa 2015.

Morel N, Palier B., Palme J., Wykraczajac poza dotychczasowe rozumienie państwa opiekuńczego?, [w:] N. Morel, B. Palier, J. Palme, Polityka społeczna jako inwestycja, Wyższa Szkoła Pedagogiczna im. Janusza Korczaka w Warszawie, Warszawa 2015.

Nicholls J. et al., A Guide to Social Return on Investment, Cabinet Office 2009.

Oramus M., Przydatność metody Social Return on Investment dla małych podmiotów ekonomii społecznej. Studium przypadku fundacji Ale heca!, „Ekonomia Społeczna” 2011, nr 2.

Social Investment Package, Evidence on Demographic and Social Trends Social Policies' Contribution to Inclusion, Employment and the Economy, Communication from the Commission to the European Parliament, the Council, the European Economic and Social Committee and the Committee of the Regions: Towards Social Investment for Growth and Cohesion - including implementing the European Social Fund 2014-2020, 20.2.2013, SWD 2013, 38 final I/I, Brussels.

Taylor-Gooby P., New risks and social change, [w:] New Risks, New Welfare: The Transformation of the European Welfare State, red. P. Taylor-Gooby, Oxford University Press, London 2004.

Vandenbroucke F., Vleminckx K., Disappointing poverty trends: Is the social investment state to blame?, „Journal of European Social Policy” 21, 2011, nr 5.

Wiktorska-Święcka A. et al., Report on scientific literature review on the concept „Social Investment”. A deliverable of the project: „Innovative Social Investment: Strengthening communities in Europe” (InnoSI), European Commission - Horizon 2020, European Commission, Research Executive Agency, Brussels 2016.

Wiktorska-Święcka A., Moroń D., Klimowicz M., Zarzadzanie innowacjami społecznymi. Trendy, perspektywy, wyzwania, Wydawnictwo Difin, Warszawa 2015. 


\section{Applying Social Return on Investment (SROI) to measure the effectiveness of social projects}

Keywords: Social Return on Investment, SROI, social projects, effectiveness of social projects, investment social policy, social investment

\section{Summary}

The article presents the results of research on the possibility of applying the Social Return on Investment (SROI) methodology for the valuation of the economic results of social projects. The aim of the article is to present the possibility of using the SROI analysis as an indicator for measurement of the effectiveness ofsocial projects. In this context, the hypothesis has been put that the Social Return on Investment (SROI) can be a useful tool for evaluating and forecasting the effectiveness of a social project. The article presents the research results obtained in the frames of the research project: "Innovative Social Investment Strengthening Communities in Europe" (InnoSi), funded by the European Commission Programme Horizon 2020. 